\title{
KAJIAN PREFERENSI KONSUMEN BERAS “IR 64" DAN FAKTOR-FAKTOR YANG MEMPENGARUHI TINGKAT KONSUMSINYA DI KOTA BENGKULU
}

\author{
Ahmad Rayendra
}

\begin{abstract}
The objective of this research were ; 1) to know the level of consumer preference toward IR 64 rice and it's related with the level of IR 64 nice consumption in Bengkulu city; 2) to know the factors the influence the level of IR 64 rice consumption in Bengkulu City. This research conducted in 4 big market in Bengkulu City like pasar Minggu, Panorama market, Baru Koto market, and Pagar Dewa market. Accidental sampling method used to determined the number of sample. The information, that used in this research based on primary and secondary data. Analysis method that used in this research were rank spearman correlation test and multiple regression test. The result of this research shown that most of consumer was in "very like" of preference level. The result of analysis shown that most of consumer was in "agree" of preference level or attribute like taste, smell, color, texture, packaging and easy for getting, price and quality. While, for attribute like proudly and practice most of consumer was in "disagree" of preference level. Multiple regression analysis shown that the factors like income and number of family member influence the consumption of IR 64 rice while the factors like price of IR 64 and price of other variety of rice uninfluenced the consumption of IR 64.
\end{abstract}

Keyword : Rice, IR 64, preference, consumption, rank spearman correlation test and multiple regression.

\section{PENDAHULUAN}

Konsumsi pangan dengan gizi yang cukup serta seimbang merupakan salah satu faktor penting yang menentukan tingkat kesehatan dan intelegensia manusia. Tingkat kecukupan konsumsi pangan dan gizi seseorang akan mempengaruhi keseimbangan perkembangan jasmani dan rohani yang bersangkutan. Sementara itu, tingkat dan pola konsumsi pangan dan gizi rumah tangga dipengaruhi oleh kondisi ekonomi, sosial, dan budaya setempat.

Kota Bengkulu merupakan ibu kota dari Propinsi Bengkulu yang mempunyai jumlah penduduk sebanyak 1.593.495 jiwa pada tahun 2005 (Dinas Pertanian dan Ketahanan Pangan Provinsi Bengkulu 2005) Perekonomian propinsi terpusat pada Kota 
Bengkulu, sehingga konsumsi pangan kota Bengkulu lebih mendominasi dibandingkan kabupaten lain sehingga beras yang beredar di pasaran sangat beragam kualitas dan kuantitasnya. Keragaman tersebut karena semakin banyaknya produksi beras dengan berbagai varietas-varietas unggul. Melimpahnya beras yang memenuhi pasaran membuat konsumen lebih leluasa untuk memilih jenis beras. Adanya faktor sosial dan lingkungan baik secara langsung maupun tidak langsung berpengaruh terhadap perilaku manusianya, termasuk perilaku mereka dalam pembelian suatu produk. Kondisi masyarakat dan sifat khas beras pada akhirnya berdampak terhadap preferensi dan pola perilaku mengkonsumsi suatu beras dimana sebagai suatu produk, beras tentu tak terlepas dari atribut kebendaan yang dimilikinya. Beras "IR 64" merupakan salah satu beras yang termasuk beras berkualitas baik yang dipasarkan di Kota Bengkulu di samping beras Lampung Asalan, Manggis dan Karawang. Sementara beras-beras tersebut dari segi kualitas tidak jauh berbeda. Namun demikian beras "IR 64" hingga saat ini masih lebih banyak diminati oleh para konsumen, untuk lebih jelas dapat dilihat pada tabel 1

Tabel 1. Volume Penjualan Beras di Kota Bengkulu

\begin{tabular}{llll}
\hline No & Merk/jenis Beras & Volume Penjualan Beras $(\mathbf{K g})$ & Persentase $(\%)$ \\
\hline 1. & IR 64 & 45.237 & 23,31 \\
2. & Lampung Asalan & 30.282 & 15,61 \\
3. & Manggis & 16.960 & 8,74 \\
4. & Lampung Super & 13.482 & 6,95 \\
5 & Merk lain & 88.089 & 45,39 \\
\hline & Jumlah & $\mathbf{1 9 4 . 0 5 0}$ & $\mathbf{1 0 0 , 0 0 \%}$ \\
\hline
\end{tabular}

Sumber : Badan Pusat Statistik Provinsi Bengkulu, Oktober 2005

Dari data di atas dapat dilihat bahwa di Kota Bengkulu tingkat penjualan beras jenis "IR 64" adalah yang paling tinggi, hal tersebut memperlihatkan bahwa beras jenis "IR 64" adalah jenis beras yang paling digemari oleh konsumen di Kota Bengkulu, sehingga hal tersebut mendorong peneliti untuk mengetahui tingkat preferensi konsumen beras "IR 64" dan faktor-faktor apakah yang mempengaruhi tingkat konsumsi beras "IR 64" tersebut. 


\section{METODOLOGI PENELITIAN}

Penelitian ini dilaksanakan di 4 pasar besar di Kota Bengkulu yaitu di Pasar Minggu, Pasar Panorama, Pasar Baru Koto dan Pasar Pagar Dewa. Penentuan lokasi penelitian dilakukan secara purposive, yaitu pengambilan lokasi secara sengaja dengan alasan bahwa pada pasar-pasar tersebut merupakan tempat terjadinya transaksi berbagai macam merek beras baik dari dalam maupun luar propinsi. Di samping itu pasar-pasar tersebut merupakan pasar-pasar besar yang terdapat di Kota Bengkulu, sehingga seluruh aktivitas jual beli beras terpusat pada empat pasar besar itu.

Populasi dalam penelitian ini adalah konsumen rumah tangga yang mengkonsumsi beras “IR 64" sebagai bahan pangan pokok. Dalam menentukan responden digunakan metode "Accidental sampling" menurut Sugiyono dalam Mucharam (2002) metode accidental sampling adalah metode pengambilan sampel yang dilakukan berdasarkan kebetulan. Dengan demikian siapa saja yang sedang berbelanja beras jenis IR 64 di toko/pedagang dan secara kebetulan bertemu penulis dan memenuhi kriteria yang telah ditentukan maka dapat dijadikan sebagai responden, yaitu konsumen harus sudah pernah membeli beras "IR 64" minimal 2 kali. Menurut Hadi (1998) bahwa tidak ada ketentuan mutlak berapa persen suatu sampel harus diambil dari suatu populasi yang tidak diketahui jumlahnya melainkan berdasarkan homogenitas dan teknik pengambilan sampel itu sendiri. Jumlah sampel dalam penelitian ini sebanyak 100 responden, diambil dari 4 Pasar di Kota Bengkulu, yaitu Pasar Pagar Dewa 3 pedagang pengecer, Pasar Baru Koto 2 pedagang pengecer, Pasar Minggu dan Pasar Panorama masing-masing 10 pedagang pengecer, untuk setiap pedagang pengecer diambil 4 responden.

Faktor preferensi konsumen beras "IR 64" secara garis besar akan digambarkan secara deskriptif dan juga akan dihitung dalam skor Pengukuran parameter preferensi 
didasarkan pada beberapa pertanyaan untuk masing-masing indikator preferensi degan tiga alternatif jawaban dimana untuk jawaban $\mathrm{a}=\mathrm{ya}, \mathrm{b}=$ ragu-ragu, $\mathrm{c}=$ tidak, masing-masing diberi skor 3,2,1 untuk pertanyaan dan pernyataan positif. Untuk mengetahui apakah preferensi berhubungan dengan tingkat konsumsi beras "IR 64" di Kota Bengkulu dilakukan dengan menggunakan analisis Statistik Non Parametrik yaitu uji korelasi Rank Spearman (Siegel, 1998) dengan formulasi sebagai berikut:

$$
r s=1-\frac{6 \sum d i^{2}}{N\left(N^{2}-N\right)}
$$

Keterangan :

rs : Koefisien rank spearman

$\mathrm{N} \quad$ : Jumlah sampel

Di : Selisih antara rangking satu variabel pengaruh dengan rangking variabel terpengaruh pada sampel atau responden ke -1

Untuk menguji signifikannya maka digunakan uji t, dimana t hitung dapat dicari dengan rumus sebagai berikut :

$$
t_{\text {hitung }}=\sqrt{\frac{N-2}{1-r s^{2}}}
$$

Nilai $t$ hitung dibandingkan dengan $t$ tabel dengan tingkat kepercayaan 95\% $(\alpha=0,05)$ dengan kaidah pengukuran hipotesa sebagai berikut :

- Jika $\mathrm{t}$ hitung $>\mathrm{t}$ tabel atau $-\mathrm{t}$ hitung $<-\mathrm{t}$ tabel maka terima Hi tolak Ho artinya, variabel bebas berhubungan nyata terhadap variabel tak bebas.

- Jika t hitung $\leq \mathrm{t}$ tabel maka tolak Hi dan terima Ho artinya, variabel bebas tidak berhubungan nyata terhadap variabel tak bebas

Dimana:

Ho : Variabel yang diuji tidak berhubungan nyata

Hi : Variabel yang diuji berhubungan nyata

Model analisis untuk mengetahui faktor-faktor yang mempengaruhi tingkat konsumsi beras "IR 64" oleh konsumen di Kota Bengkulu dilakukan dengan menggunakan model fungsi regresi linier berganda (Supranto. 1993) 


$$
Y R=a+b_{1} X_{1}+b_{2} X_{2}+b_{3} X_{3}+b_{4} X_{4}+e
$$

Dimana:

YR : Tingkat konsumsi beras “IR 64" (kg/bulan)

a : Konstanta

b1-b4 : Koefisien regresi

$\mathrm{X} 1$ : Pendapatan keluarga konsumen(Rp/ bulan)

X2 : Harga beras"IR 64” (Rp/kg)

X3 : Harga beras Lampung Asalan $(\mathrm{Rp} / \mathrm{kg})$

X4 : Jumlah anggota keluarga (orang)

e : Standard error

Pengujian hipotesa dilakukan dengan menggunakan uji serentak (uji F) yaitu untuk mengetahui pengaruh secara bersama-sama dari masing-masing faktor yang mempengaruhi konsumsi yaitu : (Sudjana, 1983)

$$
F_{\text {hitung }}=\frac{R^{2} /(k-1)}{\left(1-R^{2}\right)(n-k-1)}
$$

Dimana :

$\mathrm{R}^{2} \quad$ : Koefisien determinasi yang akan dicari

$\mathrm{k} \quad$ : Jumlah variabel termasuk intercept

n : jumlah sampel

Dengan kriteria keputusan:

- F hitung > F tabel maka terima Ha dan tolak Ho artinya, variabel bebas berpengaruh nyata terhadap variabel tak bebas.

- $\mathrm{F}$ hitung $\leq \mathrm{F}$ tabel maka terima Ho dan tolak Ha artinya, variabel bebas tidak berpengaruh nyata terhadap variabel tak bebas.

Dimana :

Ho : Variabel yang diuji tidak berpengaruh nyata

Hi : Variabel yang diuji berpengeruh nyata

Untuk menguji pengaruh dari masing-masing variabel secara terpisah (parsial) digunakan uji t (uji dua arah) yaitu: (Sudjana, 1983) 


$$
t_{\text {hitung }}=\frac{b_{i}}{S b_{i}}
$$

Dimana:

bi : Koefisien regresi

$\mathrm{Sb}_{\mathrm{i}} \quad$ : Standard error dari koefisien regresi

Dengan kriteria keputusan

- Jika $\mathrm{t}$ hitung $>\mathrm{t}$ tabel atau $-\mathrm{t}$ hitung $<-\mathrm{t}$ tabel maka terima Ho tolah Hi artinya, secara parsial variabel bebas berpengaruh nyata terhadap variabel tak bebas

- Jika t hitung $\leq \mathrm{t}$ tabel maka tolak Ho dan terima Hi artinya, secara parsial variabel bebas tidak berpengaruh nyata terhadap variabel tak bebas

Dimana:

Ho : Variabel yang diuji tidak berpengaruh nyata

Hi : Variabel yang diuji berpengaruh nyata

\section{HASIL DAN PEMBAHASAN}

\section{Analisis Preferensi Konsumen Beras "IR 64"}

Menurut Bilas dalam Hotman (1980) teori preferensi didasarkan atas gagasan sederhana dimana seorang konsumen akan memutuskan membeli sekelompok barang tertentu karena ia lebih menyenangi sekelompok barang satu dari pada sekumpulan barang yang lain.

Dari hasil penelitian dengan menggunakan uji statistik non parametrik diketahui bahwa preferensi berhubungan nyata dengan tingkat konsumsi beras "IR 64" hal ini dapat dilihat dari hasil uji t yang menunjukkan bahwa t hitung $(2,599)$ lebih besar dari t tabel $(1,983)$, seperti terlihat pada tabel 7. Dengan demikian hipotesa alternatif $\left(\mathrm{H}_{1}\right)$ diterima dan hipotesa nol $\left(\mathrm{H}_{0}\right)$ ditolak 
Tabel 9. Hasil Analisis Preferensi Konsumen Beras "IR 64"

\begin{tabular}{llll}
\hline Variabel Bebas & rs & rs $^{2}$ & T $_{\text {hitung }}$ \\
\hline X (Preferensi IR 64) & 0.254000 & 0.064516 & $2.599732 *$ \\
\hline
\end{tabular}

Sumber: Data Diolah, 2007 (lampiran 7)

Ket $\quad: *$ signifikan pada taraf kepercayaan $95 \%$

t- tabel : 1,983715

Penelitian di atas menunjukkan bahwa jika konsumen lebih menyukai terhadap suatu barang maka tingkat konsumsinya juga akan meningkat terhadap barang tersebut. Hal ini juga terlihat pada penelitian ini, bahwa responden yang mempunyai tingkat kesukaan tinggi terhadap beras "IR 64", maka tingkat pembeliannya juga akan meningkat.

\section{Faktor-faktor yang mempengaruhi konsumsi beras "IR 64"}

Untuk melihat pengaruh pendapatan, harga beras "IR 64", harga beras lain dan jumlah anggota keluarga terhadap tingkat konsumsi beras "IR 64" maka dianalisis dengan menggunakan metode regresi linier berganda. Hasil analisis dapat dilihat pada tabel. 8

Tabel. 8 Hasil estimasi tingkat konsumsi beras "IR 64” di Kota Bengkulu

\begin{tabular}{llll}
\hline Variabel Pengaruh & Koefisien regresi & Standar error & T hitung \\
\hline Pendapatan keluarga & $3,9612 \times 10^{-6}$ & $9,210 \times 10^{-7}$ & $4,3008^{*}$ \\
Harga beras "IR 64" & $-0,0047$ & 0,010 & $-0,4729$ \\
Harga beras Lampung Asalan & $-0,0019$ & 0,001 & $-1,7867$ \\
Jumlah anggota keluarga & 4,9667 & 0,626 & $7,9230^{*}$ \\
\hline t tabel $\quad: \mathbf{1 , 9 8 3}$ & & & \\
F hitung $\quad: \mathbf{3 0 , 8 7 6}$ & & & \\
F tabel $\quad: \mathbf{2 , 4 6}$ & & & \\
$\mathbf{R} \quad: \mathbf{0 , 7 5 1}$ & & & \\
$\mathbf{R}^{2}$ & $\mathbf{0 , 5 6 5}$ & & \\
\hline
\end{tabular}

Sumber: Data Diolah, 2007 (lampiran 4)

Ket: * : signifikan pada taraf kepercayaan $95 \%$

Dari hasil pengolahan data hasil penelitian diperoleh koefisien determinasi $\left(\mathrm{R}^{2}\right)$ 
sebesar 0,5652 yang berarti perubahan tingkat konsumsi beras "IR 64" dipengaruhi oleh besarnya tingkat pendapatan keluarga, harga beras "IR 64", harga beras lain dan jumlah anggota keluarga sebasar 56,52 \%. Sedangkan sisanya yang sebesar 43,48 \% dipengaruhi oleh faktor lain yang tidak dimasukkan dalam penelitian ini misalnya faktor pendidikan atau kebiasaan. Keeratan hubungan antara pendapatan keluarga, harga beras "IR 64", harga beras Lampung Asalan dan jumlah anggota keluarga ditunjukkan oleh koefisien korelasi (R). Dari hasil perhitungan diperoleh nilai $\mathrm{R}$ sebesar 0,751 yang berarti bahwa pendapatan keluarga, harga beras "IR 64", harga beras Lampung Asalan dan jumlah anggota keluarga mempunyai korelasi terhadap tingkat konsumsi beras "IR 64" di Kota Bengkulu.

Pengujian yang dilakukan secara menyeluruh dengan menggunakan uji F diperoleh hasil bahwa F hitung $(30,876)>\mathrm{F}$ tabel $(2,46)$. Hal ini menunjukkan bahwa variabel bebas yang terdiri dari pendapatan keluarga, harga beras "IR 64", harga beras lain dan jumlah anggota keluarga secara bersama-sama berpengaruh terhadap tingkat konsumsi beras "IR 64".

Dari data tersebut di atas maka dapat disusun persamaan regresi sebagai berikut:

$$
\begin{array}{r}
Y=40.3043+3,9612 \times 10^{-6} \times 1+-0,0047 \times 2+-0,0019 \times 3+4,9667 \times 4 \\
\left(9,210 \times 10^{-7}\right) \quad(0,010) \quad(0,001) \quad(0,626)
\end{array}
$$

Pengaruh masing-masing faktor pendapatan keluarga, harga beras "IR 64", harga beras Lampung Asalan serta jumlah anggota keluarga dalam penelitian ini terhadap tingkat konsumsi beras "IR 64" masyarakat Kota Bengkulu akan dijelaskan secara rinci sebagai berikut.

\section{a. Pendapatan}

Dari hasil perhitungan regresi linier berganda didapat koefisien regresi untuk pendapatan keluarga sebesar $3,961 \times 10^{-6}$ yang berarti setiap kenaikan pendapatan sebesar 1 rupiah maka akan meningkatkan konsumsi beras "IR 64" sebesar 3,961 X $10^{-6} \mathrm{Kg}$. Nilai 
t hitung $(4,301)$ lebih besar dari pada t tabel $(1,98)$, sehingga pendapatan keluarga berpengaruh nyata terhadap tingkat konsumsi beras "IR 64". Dengan demikian hipotesa alternatif $\left(\mathrm{H}_{1}\right)$ diterima dan hipotesa nol $\left(\mathrm{H}_{0}\right)$ ditolak .

Hasil penelitian ini sesuai dengan pendapat Kotler (1995) bahwa semakin tinggi tingkat pendapatan seseorang maka akan semakin tinggi daya belinya terhadap barang atau jasa dan akan semakin leluasa menentukan pilihan. Penelitian Perahayati (1997) juga mengatakan bahwa pendapatan yang tinggi memberi peluang lebih banyak bagi konsumen untuk membeli barang atau jasa yang lebih baik.

\section{b. Harga Beras "IR 64"}

Berdasarkan teori permintaan menyatakan bahwa jika harga barang naik maka permintaan akan barang tersebut akan turun. Harga beras "IR 64" mempunyai t hitung sebesar -0,472 yang lebih besar dari pada t tabel sebesar - 1,98. Hal ini berarti harga beras "IR 64" tidak berpengaruh nyata terhadap tingkat konsumsi beras "IR 64".

Teori permintaan menyatakan bahwa jika harga barang naik maka permintaan akan barang tersebut turun, tidak sesuai dengan kenyataan yang ada di lapangan pada saat dilakukan penelitian. Keadaan ini disebabkan oleh beberapa alasan. Pertama, Beras merupakan bahan makanan pokok, meskipun terjadi perubahan pada harga beras tersebut konsumen akan tetap berusaha untuk membeli. Kedua, ada konsumen yang sudah terbiasa mengkonsumsi satu jenis beras (termasuk "IR 64") sehingga konsumen tersebut sulit/enggan untuk berpaling atau pindah ke beras jenis lain.

\section{c. Harga Beras Lampung Asalan}

Hasil analisis uji t menunjukkan bahwa nilai t hitung sebesar -1,786 lebih besar dari pada t tabel -1,98. Hal ini menunjukkan bahwa harga beras "Lampung Asalan" tidak berpengaruh terhadap tingkat konsumsi beras "IR 64" dengan demikian hipotesa alternatif $\left(\mathrm{H}_{1}\right)$ ditolak dan hipotesa nol $\left(\mathrm{H}_{0}\right)$ diterima. 
Hasil penelitian ini bertentangan dengan teori permintaan yang menyatakan bahwa jika harga barang lain naik maka permintaan akan barang tersebut akan naik. tetapi karena beras "Lampung Asalan" merupakan barang yang sejenis dengan beras "IR 64" maka kenyataannya apabila terjadi kenaikan atau penurunan harga terhadap satu jenis beras, maka keadaan yang sama juga akan terjadi terhadap jenis beras lainnya atau dengan kata lain jika harga beras "Lampung Asalan" naik (tinggi) maka harga beras "IR 64" juga naik tinggi. Sehingga konsumen beras "IR 64" akan tetap memilih beras ini meskipun terjadi kenaikan atau penurunan harga beras Lampung Asalan.

\section{d. Jumlah Anggota Keluarga}

Hasil analisis yang telah dilakukan menunjukkan bahwa jumlah anggota keluarga berpengaruh nyata terhadap tingkat konsumsi beras "IR 64". Hal ini dapat disimpulkan karena nilai t hitung 7, 923 lebih besar daripada t tabel sebesar 1,98. Nilai koefisien regresi sebesar 4,966 yang berarti bahwa setiap kenaikan jumlah anggota keluarga sebanyak 1 orang maka tingkat konsumsi beras "IR 64" akan meningkat sebanyak 4,966 kg per bulan. Dengan demikian hipotesa alternatif $\left(\mathrm{H}_{1}\right)$ diterima dan hipotesa nol $\left(\mathrm{H}_{0}\right)$ ditolak

Selanjutnya dapat dikatakan hasil penelitian di atas sesuai dengan penelitian Yuningsih (1998), yang menyatakan bahwa jumlah anggota keluarga sangat mempengaruhi tinggi rendahnya tingkat konsumsi terhadap suatu barang atau jasa, semakin banyak jumlah anggota keluarga maka tingkat konsumsi suatu produk akan tinggi, juga sebaliknya semakin sedikit jumlah anggota keluarga maka tingkat konsumsi suatu produk akan rendah. Hal ini juga sejalan dengan penelitian yang dilakukan Wahyudi (1995) yang mengatakan bahwa peningkatan jumlah konsumsi antara lain dikarenakan adanya penambahan jumlah anggota keluarga. 


\section{KESIMPULAN DAN SARAN}

\section{Kesimpulan}

Berdasarkan hasil penelitian dan pembahasan dapat diambil kesimpulan sebagai berikut:

1. hasil skoring tingkat preferensi menunjukkan bahwa rasa merupakan atribut yang paling berhbungan dengan responden sebesar $85 \%$ berada pada indikator sutuju. Sementara gengsi merupakan atribut yang paling tidak berhubungan dengan responden sebesar $85 \%$ berada pada indikator tidak setuju. Secara keseluruhan atribut berupa rasa, aroma, warna, tekstur, kemasan, mudah didapat, harga dan kualitas sebagian besar responden berada pada indikator setuju, sedangkan untuk atribut kebanggan dan gengsi berada pada indikator tidak setuju.

2. hasil uji statistik nonparametrik preferensi berhubungan nyata dengan tingkat konsumsi beras 'IR 64'.

3. hasil analisis regresi linear berganda menunjukkan bahwa faktor pendapat dan jumlah anggota keluarga berpengaruh nyata terhadap konsumsi beras 'IR 64', sedangkan harga beras 'IR 64' dan harga beras lain tidak berpengaruh nyata.

\section{Saran}

Mengingat pentingnya atribut bagi konsumen sebagai faktor-faktor yang mempunyai hubungan dengan tingkat preferensi maka sebaiknya para produsen diharapakan mampu meningkatkan kualitas dari hasil produksi. Selain itu juga produsen juga diharapkan mampu memperbaiki sistem pemasaran serta memperluas pangsa pasar mereka agar para konsumen dapat dengan mudah memperoleh produk beras IR 64 ini.

\section{DAFTAR PUSTAKA}

Kotler, Philip. 1993. Manajemen Pemasaran, Analisis Perencanaan Dan Pengendalian, Jilid I, LPFE

Muslimah, A. 2001, Analisis Permintaan dan Efisiensi Pemasaran Kubis Pada Tingkat 
PedagangPengecer Kota Bengkulu, Skripsi Fakultas Ekonomi Universitas Bengkulu (Tidak Untuk di Publikasikan)

Musselman, A, dan H.J Jakcson. 1994, Pengantar Ekonomi Perusahaan, Edisi Kesembilan, Penerbit Erlangga, Jakarta

Nainggolan,, 2005. Dewan Ketahanan Pangan. Bengkulu

Siegel, S,1988, Statistik Non Parametrik. Gramedia, Jakarta

Sudjana, 1983, Metode Statistik. Tarsito, Bandung.

Sukirno, Sudono.1996. Pengantar Teori Ekonomi Makro, PT, Raja Grafindo Persada, Rajawali Pers, Jakarta

Supranto, J, 1990. Tekhnik Riset Pemasaran dan Ramalan Penjualan, Rineka Cipta, Jakarta

Swasta, Basu DH. Dan T. Hani Handoko. 1982, Manajemen Pemasaran dan Analisis Perilaku Konsumen, Liberti, Yogyakarta

Swasta, Basu, DH. dan W, Ibnu Sukotjo.1997, Pengantar Bisnis Modern (Pengantar Ekonomi Perusahaan Modern), Edisi Kelima, Liberty, Yogyakarta 